\title{
A Substrate Made from Açaí Berry Waste Used in the Production of Aroeira (Myracrodruon urundeuva) Seedlings
}

\author{
Roldão Carlos Andrade Lima ${ }^{1^{*}}$, Adriana de Sousa Freitas ${ }^{2}$, \\ Andressa Layane Ferreira Linhares ${ }^{2}$, Bianca Pinheiro da Costa Neiva ${ }^{2}$, \\ Brunna Tavares da Silva Brito Sousa ${ }^{2}$, Kaio Lucena Vidal ${ }^{2}$, \\ Dalton Henrique Angelo ${ }^{3}$ and Wilson Araujo da Silva ${ }^{2}$ \\ ${ }^{1}$ Center for Agrarian Sciences and Engineering, Federal University of Espírito Santo, Brazil. \\ ${ }^{2}$ Center for Agrarian Sciences, State University of Tocantine Region of Maranhão, Brazil. \\ ${ }^{3}$ Natural Resources Division, STCP Project Engineering Ltd., Brazil.
}

Authors' contributions

This work was carried out in collaboration among all authors. Authors RCAL, BTSBS, DHA and WAS designed the study, performed the statistical analysis, wrote the protocol and wrote the first draft of the manuscript. Authors ALFL, BPCN and KLV performed the data collection, managed the analyses of the study and the literature searches. All authors read, reviewed and approved the final manuscript.

Article Information

DOI: $10.9734 / A R R B / 2019 / v 33 i 430126$ Editor(s):

(1) Dr. Amit Kesarwani, Assistant Professor, Department of Agronomy, College of Agriculture, G.B. Pant University of Agriculture \& Technology, India. (2) Dr. Md. Aminur Rahman, Professor, Department of Fisheries and Marine Bioscience, Faculty of Biological Science and Technology, Jashore University of Science and Technology, Bangladesh. (3) Paola Angelini Department of Applied Biology, University of Perugia, Perugia, Italy. Reviewers:

(1) Poloko Emmanuel Mosebi, National University of Lesotho, Lesotho. (2) Muhamad Hafiz Abd Rahim, Universiti Putra Malaysia, Malaysia. Complete Peer review History: http://www.sdiarticle4.com/review-history/52032

Original Research Article

Received 07 August 2019

Accepted 12 October 2019

Published 28 October 2019

\begin{abstract}
The açaí berry processing activity generates a large amount of waste that is a problem in several cities, mainly in the Amazon region of Brazil, due to the large production of açaí juice. This study aimed to reuse the waste from açaí berry's processing as a substrate in the production of aroeira native seedlings, studying the effects of its application and evaluating the morphological parameters results. The experiment was carried out in the greenhouse in the city of Imperatriz MA, with waste collection carried out in 2015. After collection, part of the waste was charred and
\end{abstract}


transformed into the substrate through grinding and sieving. Subsequently, the substrates were mixed with the local soil in different proportions. Thus, the 9 treatments were obtained. To test the substrate the native aroeira species was used. The effects of different treatments were evaluated $15,30,45$ and 60 days after germination, by plant height $(H)$, neck diameter (ND) and leaf number $(\mathrm{NL})$. The results showed that the use of this residue is not promising as a substrate because they do not have good performances for the parameters evaluated in the seedlings.

Keywords: Açaí waste; reuse; substrate.

\section{INTRODUCTION}

The açaí palm (Euterpe oleracea Mart.) is a native species from the Amazon region, with its predominance registered in the northern and northeastern regions of Brazil, mainly in floodplain soils. The fruit of the palm is called açaí berry and it is highly nutrient-rich [1].

One of the most profitable commercial possibilities offered by the açaí berry is the production and marketing of açaí juice. Juice processing for the local market is a low-cost activity with an excellent economic return. However, during the processing of the fruit, a large number of residues (seeds-type byproduct) are generated and, in most cases, improperly disposed of in the environment. Its residues are becoming a potential pollutant for the population, resulting in pathogen proliferation and generating an unpleasant odour [2,3].

In an attempt to minimize the environmental impacts caused by solid waste, the Brazilian government instituted the national solid waste policy, Law No. 12305, of August 2, 2010, whose objectives correspond to environmental quality and environmental health protection, with emphasis on the end of solid waste generation linked to its reduction, reuse, recycling and treatment, as well as environmentally appropriate final disposal [4].

Studies conducted on the nutritional potential of açai berry indicated that it is rich in protein and minerals, among them include potassium (K), calcium (Ca), magnesium (Mg), iron (Fe), copper $(\mathrm{Cu})$, zinc $(\mathrm{Zn})$ and phosphorus $(\mathrm{P})$. After juice extraction, these minerals are still present in the discarded waste $[5,6]$.

Among these minerals, some may supply nutritional deficiencies suffered by the soil. The largest soil micronutrient deficiencies are most frequently observed in the field in the following order: phosphorus $(P)>$ nitrogen $(N)>$ potassium $(\mathrm{K})>$ calcium $(\mathrm{Ca})>$ magnesium $(\mathrm{Mg})$ and for micronutrients: iron $(\mathrm{Fe})>$ boron $(\mathrm{B})>$ zinc $(\mathrm{Zn})>$ copper (Cu) [7].
The use of organic waste available in rural properties for seedling production is an source of nutrients economically important, as it reduces the costs of acquiring chemical fertilizers for this purpose [8]. Large amounts of agroforestry waste are produced in the Amazon, which can become components of substrates of great importance in forest development [9].

In this context, it is proposed to reuse solid waste from açaí berry processing as a substrate in the production of native seedlings, studying the effects of its application and evaluating the morphological parameters results.

The species chosen to test the substrate was the aroeira (Myracrodruon urundeuva Allemão), belonging to the Anacardiaceae family. This is a native species from the Brazilian Amazon and is threatened with extinction and is widely used for the recovery of degraded areas [10].

\section{MATERIALS AND METHODS}

\subsection{Experimental Location}

The experiment was carried out in a greenhouse at Maranhão State University (UEMA), Empress Higher Studies Center (CESI), located under coordinates $05^{\circ} 31$ ' 35 "S and $47^{\circ} 29^{\prime} 30^{\prime}$ W, at an altitude of 116 meters. The climate is classified as Aw, tropical climate with the dry season in winter [11].

\subsection{Substrate Management}

Açaí berry waste was collected in the first half of 2015 , in the city of Imperatriz in the state of Maranhão, northeastern Brazil. The waste was picked up at street fairs in the city where açaí juice is sold. After processing the juice, the waste had been improperly disposed of.

After collecting the waste, it was dried in the sun, to extract moisture to facilitate grinding. After drying, part of the waste was charred and the other remained natural. 


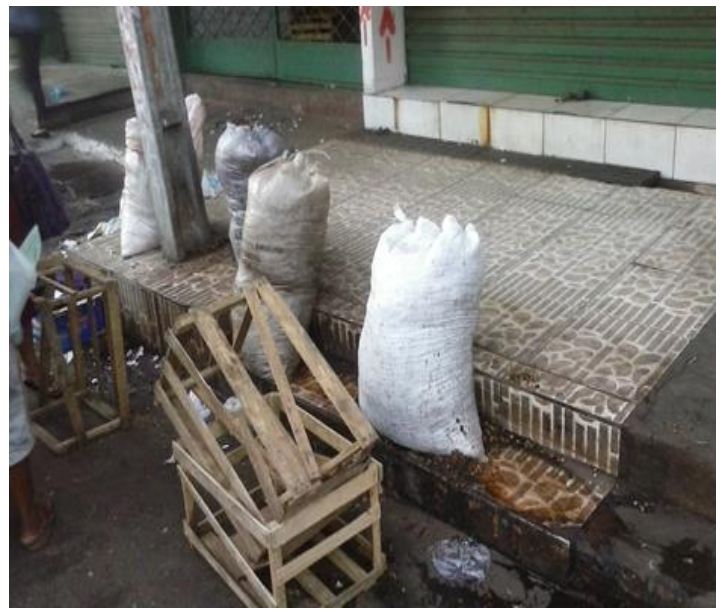

Fig. 1. Açaí berry waste disposed of incorrectly

Afterwards, the charred and natural waste were shredding, separating the resulting substrate into charred and non-charred. The local soil used for substrate mixing and as control was the Moderate Dystrophic Red-Yellow Argissol [12] collected in the $0-20 \mathrm{~cm}$ deep layer in the UEMA ICESI experimental field with chemical characteristics described in Table 1.

The first step for the implementation of the experiment was soil and substrate sieving in No. 10 ABNT sieve, eliminating coarse particles. The treatments were based on the volume of the plastic bag $\left(450 \mathrm{~cm}^{3}\right)$, consisting of different proportions of soil with two types of substrate (carbonized and non-carbonized).

The quantification of the treatments consisted as follows:

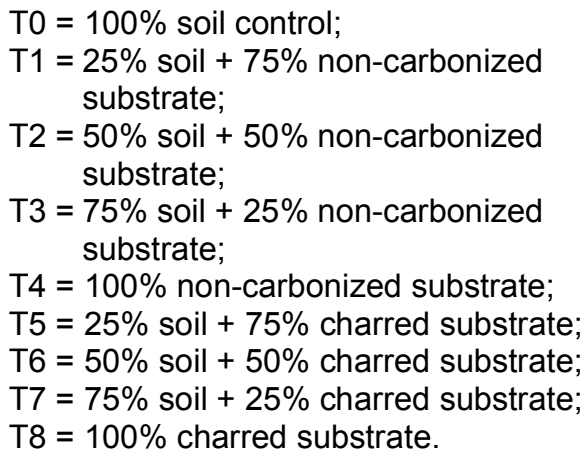

Irrigation during the experiment was done daily in the early morning and late afternoon by sprinklers installed on the upper part of the greenhouse for a minimum of 20 minutes daily.

\subsection{Plant Species}

The choice of aroeira ( $M$. urundeuva) as a test species in the experiment was because it is native to Brazil and is threatened with extinction. Also, it has a short average germination time, ranging from one to seven days, which facilitates rapid analysis of results $[10,13]$.

Table 1. Chemical analysis of moderate dystrophic red-yellow argissol

\begin{tabular}{lllllllll}
\hline $\mathbf{p H}$ & $\begin{array}{l}\mathbf{C a}^{2+}+\mathbf{M g}^{2+} \\
\mathbf{c m o l}_{\mathbf{c}} \cdot \mathbf{k g}^{-1}\end{array}$ & $\mathbf{A l} \mathbf{l}^{3+}$ & $\mathbf{H + A l}$ & $\mathbf{S B}$ & $\mathbf{C T C}$ & $\begin{array}{l}\mathbf{V} \\
\%\end{array}$ & $\begin{array}{l}\mathbf{K} \\
\mathbf{m g} \cdot \mathbf{k g}^{-1}\end{array}$ & $\mathbf{P}$ \\
\hline 5.61 & 4.69 & 1.2 & 6.5 & 6.16 & 11.6 & 43.9 & 50 & 8 \\
\hline \multicolumn{8}{c}{ Sousa et al. (2014) [14] }
\end{tabular}

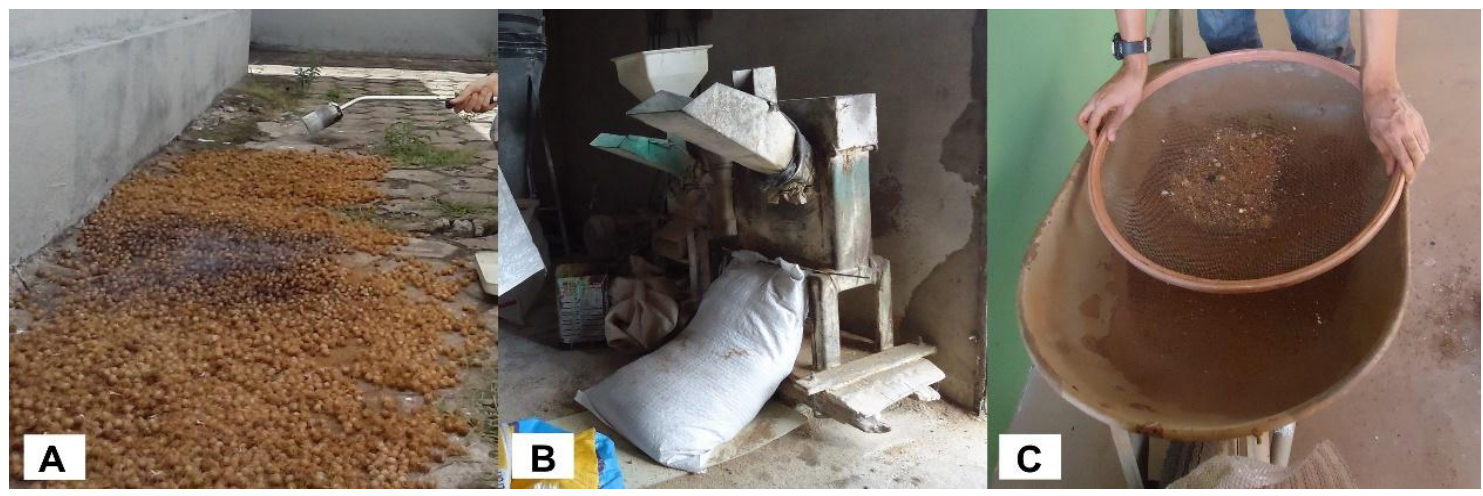

Fig. 2. A - Carbonization of açaí berry waste; B - Açaí berry waste shredding in a forage; C - Açaí berry waste substrate sieving 


\subsection{Morphological Parameters}

At 15, 30, 45 and 60 days after germination, the seedling response variables were evaluated, which consist morphological parameters of total plant height $(\mathrm{H})$, neck diameter (ND) and the number of leaves (NL).

The total height was obtained using a measuring tape and measurements were taken from ground level to the last leaf height. The neck diameter was obtained using a digital calliper with groundlevel measurements and the number of leaves was determined by direct counting, taking care to use the same standard for each individual evaluated.

\subsection{Substrate Physical \& Chemical Parameters}

The physical analysis consisted of calculations for determination of wet mass, solids mass, solids volume, density and total porosity per treatment, before and after drying performed at the UEMA / CESI Soil Laboratory. In the chemical analysis, iron oxide $\left(\mathrm{Fe}_{2} \mathrm{O}_{3}\right)$ and $\mathrm{pH}$ for carbonized substrates and for non-carbonized substrates were determined.

\subsection{Experimental Design}

For the experiment, we considered the Completely Randomized Design (CRD) composed of 8 treatments plus control, with 10 replications each. The treatments were implemented in 60 cell trays, where each experimental unit consisted of a line with 6 plants, totalling 60 plants per treatment.

Data were submitted to analysis of variance (ANOVA) and means test by Tukey with $5 \%$ probability.

\section{RESULTS AND DISCUSSION}

\subsection{Morphological Parameters}

The seedlings produced by the substrates are presented in Fig. 3. At 15 days after germination (Table 2), treatments containing smaller proportions of carbonized and non-carbonized substrate negatively influenced seedling growth for plant height response variable $(H)$. The highest height $(3.71 \mathrm{~cm})$ was observed in treatment T0, which consisted only of the local soil.

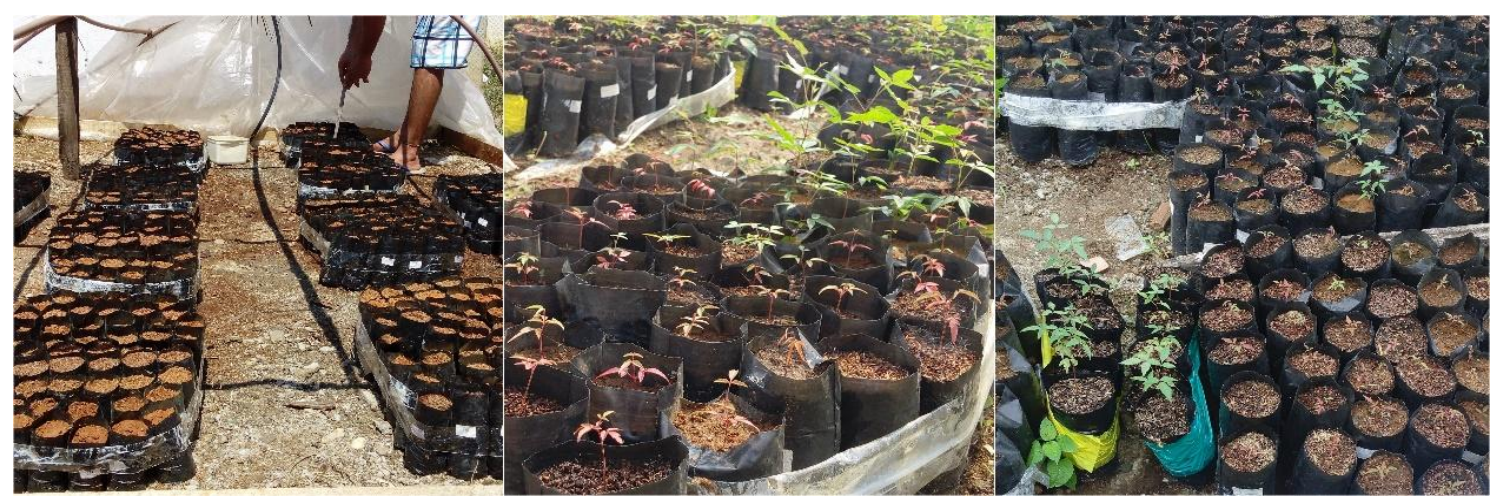

Fig. 3. Aroeira seedlings produced by charred and non-carbonized substrates

Table 2. Results obtained after 15 days of germination

\begin{tabular}{lllllll}
\hline & \multicolumn{2}{l}{ Plant height } & \multicolumn{2}{l}{ Neck diameter } & \multicolumn{2}{l}{ Number of leaves } \\
\hline T0 & 3,71 & $\mathrm{a}$ & 0,50 & $\mathrm{a}$ & 3,62 & $\mathrm{a}$ \\
T1 & 3,09 & $\mathrm{ab}$ & 0,54 & $\mathrm{a}$ & 2,96 & $\mathrm{~b}$ \\
T2 & 3,00 & $\mathrm{~b}$ & 0,54 & $\mathrm{a}$ & 3,18 & $\mathrm{~b}$ \\
T3 & 2,92 & $\mathrm{~b}$ & 0,52 & $\mathrm{a}$ & 3,08 & $\mathrm{~b}$ \\
T4 & 3,24 & ab & 0,55 & $\mathrm{a}$ & 3,14 & $\mathrm{~b}$ \\
T5 & 2,94 & $\mathrm{~b}$ & 0,54 & $\mathrm{a}$ & 2,94 & $\mathrm{~b}$ \\
T6 & 2,72 & $\mathrm{~b}$ & 0,47 & $\mathrm{a}$ & 3,07 & $\mathrm{~b}$ \\
T7 & 2,89 & $\mathrm{~b}$ & 0,55 & $\mathrm{a}$ & 3,11 & $\mathrm{~b}$ \\
T8 & 3,18 & ab & 0,54 & $\mathrm{a}$ & 2,92 & $\mathrm{~b}$ \\
\hline
\end{tabular}

Note: Means in the same column followed by different letters differ significantly $(p<0.05)$ using Tukey test 
The highest average observed among the morphological parameters of plant height $(\mathrm{H})$ and the number of leaves $(\mathrm{NL})$ at 15 days after sowing was in T0 treatment with a significant difference by Tukey test at $5 \%$ probability when compared to the other treatments. This was because the soil chosen had good proven chemical characteristics, such as high base saturation value $(\mathrm{V} \%), \mathrm{pH}$ in adequate range for crop development, high cation exchange capacity (CTC), phosphorus levels classified as medium and clayey texture [14], which favoured good water and nutrient retention capacity.

Regarding the neck diameter (ND), the means did not differ statistically between treatments, including the control (T0). The largest diameters were in treatments T2, T4, T5 and T7 (both 0.54 $\mathrm{mm})$. Regarding the variable number of leaves $(\mathrm{NL})$, the substrate means (carbonized and noncarbonized) did not differ statistically among themselves, only about T0. The fact that these parameters do not differ statistically may be due to the age of the plant, which at 15 days may not have developed properly to represent soil or substrate influence.

The analysis of the results presented in Table 3 showed that at 30 days of germination the T0 treatment presented the highest averages for all morphological parameters evaluated. The $\mathrm{H}$ and NL showed a significant difference when compared with the other treatments.

It was also possible to verify that with ND, the T0 treatment showed significant differences with T1, T2 and T4 treatments and did not differ statistically from the other treatments. The best value of T0 confirms the importance of choosing a good soil for seedling cultivation.
The ND parameter can be used to evaluate the seedlings survival capacity when transplanted in the field [15], based on this, the seedlings produced by treatments T0 $(0.74 \mathrm{~mm})$ and T3 $(0.64 \mathrm{~mm})$ are the ones that present greater field survivability.

This result is due to the soil effect on the substrate, since in these treatments the proportion of soil in the mixture is high, being $100 \%$ and $75 \%$ respectively for T0 and T3. It was also observed that there was no significant difference between non-carbonized (T3) and carbonized (T7) substrate considering the same proportion of soil and açaí substrate.

Regarding NL, the treatment with the highest average was T0 (14.19). This parameter is of great importance because it is considered an indicator of productivity, where the leaf area is responsible for the photosynthetic process of the plant [16].

Table 4 presents the result of measurements made 45 days after germination.

The analysis of the results showed that the TO treatment was highlighted with the highest averages for all parameters evaluated. Regarding $\mathrm{H}$, treatment T0 also obtained higher values and was statistically different from other treatments. The ND parameter showed a significant difference when T0 was compared to the other treatments. The lowest values for this parameter were for T6 $(0.48 \mathrm{~mm})$, T1 $(0.51 \mathrm{~mm})$ and T4 $(0.54 \mathrm{~mm})$ treatments, as they presented little or no proportion of soil. NL was also highlighted in the value of the means for T0, where it differed statistically from the other treatments, but did not present statistical differences between them.

Table 3. Results obtained after $\mathbf{3 0}$ days of germination

\begin{tabular}{lllllll}
\hline & \multicolumn{2}{l}{ Plant height } & \multicolumn{2}{l}{ Neck diameter } & \multicolumn{2}{l}{ Number of leaves } \\
\hline T0 & 5,63 & $\mathrm{a}$ & 0,74 & $\mathrm{a}$ & 14,19 & $\mathrm{a}$ \\
T1 & 3,13 & $\mathrm{~b}$ & 0,58 & $\mathrm{~b}$ & 8,32 & $\mathrm{~b}$ \\
T2 & 3,07 & $\mathrm{~b}$ & 0,58 & $\mathrm{~b}$ & 8,93 & $\mathrm{~b}$ \\
T3 & 3,09 & $\mathrm{~b}$ & 0,64 & $\mathrm{ab}$ & 8,47 & $\mathrm{~b}$ \\
T4 & 3,20 & $\mathrm{~b}$ & 0,59 & $\mathrm{~b}$ & 8,68 & $\mathrm{~b}$ \\
T5 & 3,10 & $\mathrm{~b}$ & 0,61 & $\mathrm{ab}$ & 8,76 & $\mathrm{~b}$ \\
T6 & 2,74 & $\mathrm{~b}$ & 0,60 & $\mathrm{ab}$ & 8,41 & $\mathrm{~b}$ \\
T7 & 2,66 & $\mathrm{~b}$ & 0,62 & $\mathrm{ab}$ & 8,28 & $\mathrm{~b}$ \\
T8 & 2,83 & $\mathrm{~b}$ & 0,61 & $\mathrm{ab}$ & 8,41 & $\mathrm{~b}$ \\
\hline \multicolumn{2}{c}{ Note: Means in the same column followed by different letters differ significantly $(p<0.05)$ using Tukey test }
\end{tabular}


Table 4. Results obtained after $\mathbf{4 5}$ days of germination

\begin{tabular}{lllllll}
\hline & \multicolumn{2}{l}{ Plant height } & \multicolumn{2}{l}{ Neck diameter } & \multicolumn{2}{l}{ Number of leaves } \\
\hline T0 & 7,31 & $\mathrm{a}$ & 0,90 & $\mathrm{a}$ & 16,17 & $\mathrm{a}$ \\
T1 & 3,00 & $\mathrm{~b}$ & 0,51 & $\mathrm{C}$ & 8,72 & $\mathrm{~b}$ \\
T2 & 2,78 & $\mathrm{~b}$ & 0,57 & $\mathrm{~b}$ & 8,34 & $\mathrm{~b}$ \\
T3 & 3,06 & $\mathrm{~b}$ & 0,58 & $\mathrm{~b}$ & 8,67 & $\mathrm{~b}$ \\
T4 & 3,14 & $\mathrm{~b}$ & 0,54 & $\mathrm{c}$ & 8,82 & $\mathrm{~b}$ \\
T5 & 3,14 & $\mathrm{~b}$ & 0,58 & $\mathrm{~b}$ & 9,16 & $\mathrm{~b}$ \\
T6 & 2,74 & $\mathrm{~b}$ & 0,48 & $\mathrm{C}$ & 8,57 & $\mathrm{~b}$ \\
T7 & 2,73 & $\mathrm{~b}$ & 0,55 & $\mathrm{c}$ & 7,91 & $\mathrm{~b}$ \\
T8 & 2,73 & $\mathrm{~b}$ & 0,49 & $\mathrm{c}$ & 7,77 & $\mathrm{~b}$ \\
\hline \multicolumn{7}{l}{ Note: Means in the same column followed by different letters differ significantly $(p<0.05)$ using Tukey test }
\end{tabular}

In Table 5, it can be observed that at 60 days of germination the T0 treatment continues with the highest averages in all parameters, due to the favourable soil characteristics, making the substrate contribution in the other treatments insignificant.

In general, the measures of the response variables verified that there were no significant differences in the comparison of the studied morphological parameters between the carbonized and non-carbonized substrate, considering the same proportion of soil and substrate.

\subsection{Substrate Physical \& Chemical Parameters}

It can be seen from Table 6 that physical characteristics such as substrate density and porosity are promising.

According to the physical characteristics analyzed, it was found that the treatments with the presence of substrate presented lower densities when compared to the local soil (T0). The low density is an important parameter because it interferes with the root development of plants, besides the availability of nutrients and

Table 5. Results obtained after 60 days of germination

\begin{tabular}{lllllll}
\hline & \multicolumn{2}{l}{ Plant height } & \multicolumn{2}{l}{ Neck diameter } & \multicolumn{2}{l}{ Number of leaves } \\
\hline T0 & 12,89 & $\mathrm{a}$ & 0,98 & $\mathrm{a}$ & 21,32 & $\mathrm{a}$ \\
T1 & 3,05 & $\mathrm{~b}$ & 0,33 & $\mathrm{~b}$ & 9,45 & $\mathrm{~b}$ \\
T2 & 2,82 & $\mathrm{~b}$ & 0,33 & $\mathrm{~b}$ & 8,69 & $\mathrm{~b}$ \\
T3 & 2,94 & $\mathrm{~b}$ & 0,42 & $\mathrm{~b}$ & 8,30 & $\mathrm{~b}$ \\
T4 & 3,07 & $\mathrm{~b}$ & 0,37 & $\mathrm{~b}$ & 8,78 & $\mathrm{~b}$ \\
T5 & 3,24 & $\mathrm{~b}$ & 0,45 & $\mathrm{~b}$ & 9,23 & $\mathrm{~b}$ \\
T6 & 2,85 & $\mathrm{~b}$ & 0,37 & $\mathrm{~b}$ & 8,10 & $\mathrm{~b}$ \\
T7 & 3,04 & $\mathrm{~b}$ & 0,44 & $\mathrm{~b}$ & 8,28 & $\mathrm{~b}$ \\
T8 & 2,78 & $\mathrm{~b}$ & 0,36 & $\mathrm{~b}$ & 7,77 & $\mathrm{~b}$ \\
\hline
\end{tabular}

Note: Means in the same column followed by different letters differ significantly $(p<0.05)$ using Tukey test

Table 6. Physical analysis of treatments

\begin{tabular}{|c|c|c|c|c|c|c|c|c|c|c|}
\hline \multirow{2}{*}{$\begin{array}{l}\text { Treatments } \\
\text { T0 }\end{array}$} & \multicolumn{2}{|c|}{$\begin{array}{l}\text { Wet mass } \\
\text { (g) }\end{array}$} & \multicolumn{2}{|c|}{$\begin{array}{l}\text { Solids mass } \\
\text { (g) }\end{array}$} & \multicolumn{2}{|c|}{$\begin{array}{l}\text { Solids } \\
\text { volume }\left(\mathrm{cm}^{3}\right)\end{array}$} & \multicolumn{2}{|c|}{$\begin{array}{l}\text { Density } \\
\left(\text { g.cm }{ }^{-3}\right)\end{array}$} & \multicolumn{2}{|c|}{$\begin{array}{l}\text { Total } \\
\text { porosity (\%) }\end{array}$} \\
\hline & 205,9 & $a$ & 204,50 & $a$ & 96,78 & $a$ & 2,08 & $a$ & 1,43 & $\mathrm{c}$ \\
\hline $\mathrm{T} 1$ & 166,1 & bc & 142,60 & $\mathrm{c}$ & 74,68 & $b$ & 1,45 & c & 23,94 & a \\
\hline T2 & 179,3 & $\mathrm{~b}$ & 173,90 & $\mathrm{~b}$ & 92,78 & $a$ & 1,77 & b & 5,50 & $\mathrm{c}$ \\
\hline T3 & 207,9 & $a$ & 195,50 & $a$ & 85,78 & $a b$ & 1,99 & a & 12,63 & b \\
\hline T4 & 130,6 & c & 123,10 & $c$ & 90,68 & $a$ & 1,25 & c & 7,64 & c \\
\hline T5 & 178,9 & $b$ & 174,60 & $\mathrm{~b}$ & 93,88 & a & 1,78 & b & 4,38 & c \\
\hline T6 & 184,5 & $\mathrm{~b}$ & 164,20 & bc & 77,88 & b & 1,67 & bc & 20,68 & a \\
\hline T7 & 146,6 & c & 129,20 & $\mathrm{C}$ & 80,78 & $b$ & 1,32 & c & 17,72 & $b$ \\
\hline T8 & 134,9 & c & 127,10 & c & 90,38 & a & 1,29 & c & 7,94 & c \\
\hline
\end{tabular}


water. Only the treatment $75 \%$ of soil $+25 \%$ of non- carbonized substrate (T3) showed a statistically similar density to the control, possibly due to a large amount of soil and the fact that the substrate was not carbonized.

The porosity results obtained the best values for the treatments $25 \%$ non-carbonized substrate + $75 \%$ soil (T1) and $50 \%$ carbonized substrate + $50 \%$ soil (T6). These values stood out compared to the other treatments, even control. Higher porosity values reflect a good infiltration and exchange of gases with the external environment. Usually lighter low-density substrates, such as carbonized materials, increase the macroporosity of the mixtures and reduce the substrate's water retention capacity [17].

Regarding chemical analysis, the values of variance for the determination of Iron Oxide $\left(\mathrm{Fe}_{2} \mathrm{O}_{3}\right)$ are classified as low variability $(<12 \%)$, medium variability $(12 \%<62 \%)$ and high variability (> 62\%) [18]. Following this classification, both carbonized and noncarbonized substrates were characterized as having low variability. However, when comparing both results, it is observed that the noncarbonized substrate has low variance with the carbonized substrate. Soils with high variability and iron oxide are characterized by their higher water permeability, higher erosion resistance and higher phosphorus fixation [19].

In $\mathrm{pH}$ determination, the result for both substrates was characterized as acid. These results are considered normal as they are similar to the mean values on a dry basis at $65^{\circ} \mathrm{C}$ in açai stone samples [20].

The low performance provided by the açaí substrate when compared to the control was mainly due to the high $\mathrm{C}: \mathrm{N}$ ratio, which in this type of substrate is about 48.27 [20], which was confirmed during the experiment by means of yellowing symptoms of the leaves of the aroeira ( $M$. urundeuva) seedlings after the consumption of the reserves present in the cotyledons.

\section{CONCLUSION}

The carbonized and non-carbonized açaí berry residues used as plant substrate did not perform well for the morphological parameters evaluated in aroeira seedlings and were negative when compared to the control (composed only of local soil).
The best performances were identified in the treatments composed by substrates that contained non-carbonized açaí berry residue + local soil when compared to the other treatments.

Açaí berry waste has the physical aptitude to be used as a substrate for seedling production. They are already chemically acidic soils with high C: $\mathrm{N}$ ratio. In contrast, this substrate can be used in less fertile soils for testing purposes, as well as helping species that need better soil aeration and less compaction.

\section{COMPETING INTERESTS}

Authors have declared that no competing interests exist. The products used for this research are commonly and predominantly use products in our area of research and country. There is no conflict of interest between the authors and producers of the products because we do not intend to use these products as an avenue for any litigation but for the advancement of knowledge. Also, the research was not funded by the producing company rather it was funded by personal efforts of the authors.

\section{REFERENCES}

1. Oliveira AG, Costa MCD, Rocha SMBM. Functional benefits of açai berry in the prevention of cardiovascular diseases. Journal of Amazon Health Science. 2015;1(1):1-10. English

2. Pagliarussi MS, Munari PA, Santos MO, Person JDC. Perspectives of application of operational research in the planning of the acai agroindustrial chain. $1^{\text {st }}$ Ed. São Carlos: Embrapa Instrumentation. (Org.); 2012. Portuguese

3. Brown AS, Paiva AV. Production of Physocalymma scaberrimum seedlings in substrates composed by different percentages of açai organic residue. Forest. 2012;42(2):399-408. Portuguese Available:http://dx.doi.org/10.5380/rf.v42i2. 19220

4. BRAZIL. Ministry of the Environment. Waste Management: National Solid Waste Policy. Brasilia: MMA; 2010.

5. Rogez H. Acai: Preparation, composition and conservation improvement. Bethlehem: EDUFPA. 2000;313.

6. Menezes EMS, Torres AT, Sabaa-Srur AUO. Lyophilized Acai Pulp (Euterpe oleracea, Mart.) nutritional value. Amazon Act. 2008;38(2):311-316. English 
Available:http://dx.doi.org/10.1590/S004459672008000200014

7. Gonçalves JLM. Fertilization recommendations for eucalyptus, Pinus and typical Atlantic forest species. Piracicaba: University of Sao Paulo. 1995;15. (Forestry Documents)

8. Araújo Neto SE, Azevedo JMA, Galvao RO, Oliveira EBL, Ferreira RLF. Organic production of sweet pepper seedlings with different substrates. Rural Science. 2009;39(5):1408-1413. English

Available:http://dx.doi.org/10.1590/S010384782009005000099

9. Brown AS, Paiva AV. Seedling emergence of supiaran (Alchornea discolour Poepp.) in substrate composed of different percentages of acai organic waste. REVSBAU. 2011;6(1):85-98. English

Available:http://dx.doi.org/10.5380/revsbau .v6i1.66391

10. Nunes YRF, Fagundes M, Almeida HS, Veloso MDM. Ecological aspects of aroeira (Myracrodruon urundeuva all Germany Anacardiaceae): Phenology and seed germination. Tree Magazine. 2008;32(2): 233-243. English

Available:http://dx.doi.org/10.1590/S010067622008000200006

11. Köppen W, Geiger R. Klimate der Erde. Gotha: Verlag Justus Perthes; 1928.

12. Munsell Soil Color Company. Munsell soil colour chats. Macbeth Division of Kollmorgen Corporation: Baltimore, Maryland, USA, 1950. Revised; 1975.

13. Silva LMM, Rodrigues TJD, Aguiar IB. The effect of light and temperature on the germination of Myracrodruon urundeuva German. Tree Magazine. 2002;26(6):691697. English

Available:http://dx.doi.org/10.1590/S010067622002000600006

14. Sousa LFRA, Marine RWD, Nunes FM, Costa NB, Birth IO, Silva WA. Incubation of yellow red argissol dystrophic with increasing doses of $\mathrm{CaCO} 3$ to neutralize exchangeable acidity. Agroecosystems Magazine. 2014;6(1):66-73. Portuguese

15. Daniel O, Vitorino ACT, Alovisi AA, Mazzochin L, Tokura AM, Pine ER, Souza EF. Phosphorus application in Acacia mangium Willd seedlings. Tree Magazine. 1997;21(2):163-168. Portuguese

16. Favarin JL, Golden Grandson D, Garcia AG, New NAV, Favarin MGGV. Equations for estimating the coffee leaf area index. Brazilian Agricultural Research. 2002;37(6):769-773. English

Available:http://dx.doi.org/10.1590/S0100204X2002000600005

17. Gonçalves JLM, Poggiani F. Substrates for forest seedling production. In: Latin American Soil Science Congress, 13, Piracicaba, SP. Annals ... Piracicaba, Latin American Society of Soil Science, CDROM; 1996.

18. Silva Junior JF, Marques Junior J, Camargo LA, Teixeira DB, Panosso AR, Pereira GT. Geostatistical simulation for the spatial characterization of iron oxides in different landforms. Brazilian Journal of Soil Science. 2012;36(6):1690-1703. English

Available:http://dx.doi.org/10.1590/S010006832012000600003

19. Correa MM, Ker JC, Barrón V, Fontes MPF, Torrent J, Curi N. Characterizing iron oxides from coastal and central plain soils. Revista Brasileira de Ciências do Solo. 2008;32(3):1017-1031. English Available:http://dx.doi.org/10.1590/S010006832008000300011

20. Teixeira LB, Germano VLC, Oliveira RF, Furlan Junior J. Composting processes using residues from the açaí and palm heart agro-industries. Bethlehem: Embrapa Eastern Amazon. 2005;6. (Technical Circular 41). Portuguese

(c) 2019 Lima et al.; This is an Open Access article distributed under the terms of the Creative Commons Attribution License (http://creativecommons.org/licenses/by/4.0), which permits unrestricted use, distribution, and reproduction in any medium, provided the original work is properly cited.

Peer-review history:

The peer review history for this paper can be accessed here: http://www. sdiarticle4.com/review-history/52032 